\title{
THE RECENT CONVERGENCE OF FINANCIAL DEVELOPMENT IN ASIA
}

Robert Dekle and Madhavi Pundit

NO. 440

July 2015
ADB ECONOMICS WORKING PAPER SERIES 
ADB Economics Working Paper Series

\section{The Recent Convergence of Financial Development in Asia}

Robert Dekle and Madhavi Pundit

No. 440 | July 2015
Robert Dekle (dekle@usc.edu) is Professor at the Department of Economics, University of Southern California. Madhavi Pundit (mpundit@adb.org) is Economist at the Economic Research and Regional Cooperation Department, Asian Development Bank.

This article was prepared as a background paper for the Asian Development Outlook 2015. We thank Junray Bautista for excellent research assistance.

\section{ASIAN DEVELOPMENT BANK}


Asian Development Bank

6 ADB Avenue, Mandaluyong City

1550 Metro Manila, Philippines

www.adb.org

(C) 2015 by Asian Development Bank

July 2015

ISSN 2313-6537 (Print), 2313-6545 (e-ISSN)

Publication Stock No. WPS157520-2

The views expressed in this paper are those of the authors and do not necessarily reflect the views and policies of the Asian Development Bank (ADB) or its Board of Governors or the governments they represent.

ADB does not guarantee the accuracy of the data included in this publication and accepts no responsibility for any consequence of their use.

By making any designation of or reference to a particular territory or geographic area, or by using the term "country" in this document, $A D B$ does not intend to make any judgments as to the legal or other status of any territory or area.

Note: In this publication, "\$” refers to US dollars.

The ADB Economics Working Paper Series is a forum for stimulating discussion and eliciting feedback on ongoing and recently completed research and policy studies undertaken by the Asian Development Bank (ADB) staff, consultants, or resource persons. The series deals with key economic and development problems, particularly those facing the Asia and Pacific region; as well as conceptual, analytical, or methodological issues relating to project/program economic analysis, and statistical data and measurement. The series aims to enhance the knowledge on Asia's development and policy challenges; strengthen analytical rigor and quality of ADB's country partnership strategies, and its subregional and country operations; and improve the quality and availability of statistical data and development indicators for monitoring development effectiveness.

The ADB Economics Working Paper Series is a quick-disseminating, informal publication whose titles could subsequently be revised for publication as articles in professional journals or chapters in books. The series is maintained by the Economic Research and Regional Cooperation Department. 


\section{CONTENTS}

TABLES AND FIGURES iv

ABSTRACT $v$ V

$\begin{array}{ll}\text { I. INTRODUCTION } & 1\end{array}$

II. A REVIEW OF THE RECENT LITERATURE ON DETERMINANTS OF FINANCIAL DEVELOPMENT GROWTH

III. FINANCIAL DEVELOPMENT INDICES 2

A. Financial Development Indicators 2

B. Construction of the Indices 3

IV. COMPARISON OF THE ASSOCIATION OF SOUTHEAST ASIAN NATIONS++ MEMBERS WITH THE BENCHMARK ECONOMIES

A. Where Are the ASEAN++ Economies in Relation to the Benchmark Group? 5

B. What Factors Play a Role in Levels of and Changes in Financial Development? 7

V. AN ECONOMETRIC ANALYSIS OF THE DETERMINANTS OF FINANCIAL

DEVELOPMENT GROWTH 10
A. The Data 11
B. Panel Data Econometrics $\quad 12$
C. Results

VI. WHICH ECONOMIES HAVE FINANCIAL SYSTEMS THAT PROMOTE POSITIVE ECONOMIC OUTCOMES?

$\begin{array}{lll}\text { VII. CONCLUSIONS } & 17\end{array}$

$\begin{array}{ll}\text { REFERENCES } & 19\end{array}$ 


\section{TABLES AND FIGURES}

\section{TABLES}

1 Financial Development and Its Economic Determinants, 2004-2011

2 Panel Data Random Effects Estimates (Dependent Variable: Change in Financial Development from Previous Year)

3 Panel Data Random Effects Estimates: Interactive Effects with Institutional Variables (Dependent Variable: Change in Financial Development from Previous Year)

$4 \quad$ Accounting for Economic Outcomes: Financial Development Indices

\section{FIGURES}

$1 \quad$ Bank-Based versus Market-Based Financial Structure

2 Country Indices in Relation to the Benchmark Index

3 Factors Determining Financial Development, Ranked by Gross Domestic Product per Capita and Inflation

$4 \quad$ Factors Determining Financial Development

5 Factors Determining Change in Financial Development Index 


\begin{abstract}
We construct an index of financial development for 23 Asian economies based on subindices of access, depth, and efficiency of financial institutions and markets and find evidence that economies with weaker financial systems are catching up to the Asian benchmark economies, namely Hong Kong, China; Japan; the Republic of Korea; and Singapore. Gross domestic product (GDP) per capita, aggregate GDP, and mobile subscriptions all increase the growth rate of financial development in Asian economies while institutional factors have insignificant or ambiguous effects. We also evaluate the relative importance of the subindices in delivering high economic growth, low volatility, and greater financial access.
\end{abstract}

Keywords: Asian economies, convergence to benchmark, financial development, index construction JEL Classification: C82, G01, G02 


\section{INTRODUCTION}

Having a financial system that does a good job of delivering essential services is extremely important for economic development, and ensuring strong finance sector development is crucial for growth and poverty reduction. Globalization further impacts finance sector design, providing impetus to replace domestic with international providers of finance sector services. In this paper we seek an answer to the following question: Have the rest of the Asian economies been catching up with or converging on the financial systems of the Asian economies with advanced financial systems? Our benchmark set of advanced economies includes Hong Kong, China; Japan; the Republic of Korea; and Singapore. We chose them because they are widely acknowledged to have the strongest financial systems in Asia. Using data on our benchmark group, we construct an index of financial development for all other economies in Asia and find strong evidence that Asian economies with weaker financial systems are indeed catching up to those with stronger ones.

\section{A REVIEW OF THE RECENT LITERATURE ON DETERMINANTS OF FINANCIAL DEVELOPMENT GROWTH}

The determinants of financial development have been discussed extensively in the literature. Key among them is macroeconomic background such as per capita gross domestic product (GDP), the level of GDP, and the inflation rate. Countries with a higher level of economic development (per capita GDP) need more sophisticated financial systems for the better functioning of the economy and will thus have greater growth in financial development. Richer households and firms will require more banking services and more and better financial institutions to channel savings from households to firms. There will be a greater need for institutions to transform risk, reducing it through aggregation and enabling it to be carried by those more willing to bear it.

In this regard, Ang and McKibbin (2007) studied the case of Malaysia which has a history of finance sector reforms since the 1960s and suggested that these reforms were carried out in response to per capita GDP growth that created a demand for better financial services. Demetriades and Hussein (1996) also found that per capita GDP growth led to financial development in some economies though the relation could be bidirectional in countries such as the Republic of Korea and Thailand.

Holding the level of per capita GDP or per capita GDP growth constant, the scale or the aggregate GDP level should increase a country's rate of growth of financial development. While the People's Republic of China (PRC) and Thailand may have similar levels of GDP per capita, the PRC's higher aggregate GDP level would require financial institutions of a larger scale. As financial services are characterized by increasing returns to scale, the larger the scale of the finance sector, the more efficient the financial services. The inflation rate is thought to negatively influence growth in financial development, although the converse may sometimes hold in the case of moderate inflation (Detriagiache, Gupta, and Tressel 2005).

Another macroeconomic factor is the effect of trade and financial openness on financial development. Law and Demetriades (2004) analyzed 45 developing countries and found that openness to capital and trade flows led to financial development similar to the result in Rajan and Zingales (2003). International remittance flows along with institutions were shown to have an effect on stock market depth (market capitalization) in Billmeier and Massa (2007) for economies in the Middle East and Central Asia. 
Recently, the role of electronics and telecommunications has been explored as a catalyst for financial development. Technology is being used to develop new financial channels and to change the quality of financial services delivered. For example, where access to bank branches is limited, the unprecedented reach of mobile phone networks has provided scope for improving access to branchless banking services (WEF 2011; Lyman, Pickens, and Porteous 2008).

Aside from the above variables, there is extensive literature on the role of institutions and legal systems in finance sector development and performance. Gani and Ngassam (2008) found that institutional quality was important for stock market development in Asian economies. With regard to laws, studies have demonstrated a positive relation between effective legal protection of investors and creditors and the development of capital markets and banking systems (La Porta et al. 1997; Djankov, McLiesh, and Shleifer 2007). Deakin, Demetriades, and James (2010) showed that reforms that strengthened creditor protection laws in India in the 1990s and 2000s had a positive impact on banking system development. Using a quantitative indicator of legal change over time, the creditor protection index, and the ratio of private bank credit to nominal GDP per capita for banking system development, they obtained a causal relation from legal reform to banking development independent of real income growth and stock market development.

\section{FINANCIAL DEVELOPMENT INDICES}

We consider that financial development reflects improvements in three areas: the access of individuals and firms to financial services, the efficiency of the financial institutions and markets in intermediating financial resources, and the depth of financial institutions and markets. We aggregate these three into our final measure of "financial development" used here and in our regressions later.

\section{A. Financial Development Indicators}

We chose the following seven indicators as they capture these dimensions and have the most data for our sample; they reflect both financial institutions and markets.

(i) The number of commercial bank branches per 100,000 adults. This is a proxy for access to financial services.

(ii) Net interest margin (NIM). The margin is defined as the difference between a bank's interest income and interest expense expressed as a percentage of interest-earning assets. NIM is considered to be a proxy for the efficiency of the banking system. A wide margin typically reflects frictions in intermediation; hence a low value of NIM represents higher financial development.

(iii) The stock market turnover ratio. This is the ratio of the total value of shares traded to the average market capitalization. It measures efficiency in terms of transactions in the financial market. A higher turnover implies more liquidity and greater efficiency.

(iv) $\mathrm{M} 2$ as a percent of GDP. This is a measure of money supply that includes cash, checking, and savings deposits and is commonly used as a proxy for financial depth.

(v) The ratio of domestic credit provided by the private finance sector to GDP. This measures credit to all sectors except the central government provided by banking and nonbanking financial institutions. It is a comprehensive measure of the size of the financial system. 
(vi) The ratio of stock market capitalization to GDP. This is defined as the total value of shares listed in the stock market and measures the size of the financial market.

(vii) The ratio of gross value added by the finance sector to GDP. This is a measure of size.' For all indicators except NIM, a higher value represents greater financial development. Some other measures for financial access include the percentage of firms with lines of credit and the number of borrowers and depositors in commercial banks. However, due to insufficient data coverage, we used only one measure for access, namely the number of bank branches. The description of the variables, the data sources, and other details are available from the authors upon request.

\section{B. Construction of the Indices}

We used a methodology similar to Dorrucci, Meyer-Cirkel, and Santabarbara (2009) in the construction of the financial development index. The variables measuring different aspects of the financial system cannot be grouped together as they exist. In order to aggregate them into an index, they have to be made comparable through a process of normalization.

We normalized indicator $x$ to lie in the range $(0,1)$. The rescaled indicator for an economy $i$ at time $t$ is calculated as

$$
I_{x i t}=\frac{X_{i t}}{\max _{x i t}}
$$

where the denominator refers to the highest value of the indicator for the economies that we used as a benchmark. The maximum value is taken across all time, i.e., from 2004 to 2011, to analyze the development of an indicator over time. It also allows the maximum value across time to be always higher than the value for any one economy in any particular year, so that the rescaled indicator is not greater than $1 .^{2}$

The benchmark group consists of Hong Kong, China; Japan; the Republic of Korea; and Singapore. The choice reflects the maximum level of financial development in the region across all indicators although any one economy may not present the maximum for every indicator. Having a group of economies in the benchmark instead of just one also prevents introducing bias about the structure of the financial system that is considered optimal. In our set, Japan and the Republic of Korea are more bank-based, and Hong Kong, China and Singapore are more market-based as depicted in Figure 1 which plots two indicators: stock market capitalization and domestic credit by the finance sector both as a percent of GDP.

\footnotetext{
Bangladesh; the People's Republic of China; Hong Kong, China; Indonesia; the Republic of Korea; Malaysia; Mongolia; Papua New Guinea; the Philippines; Singapore; Thailand; and Viet Nam have data on finance at current prices. Australia, Georgia, Kazakhstan, the Kyrgyz Republic, Nepal, and Pakistan have data at current basic prices. India and New Zealand have data at current factor cost. Japan and Sri Lanka have data at current producer's prices.

2 The exception is NIM for Indonesia from 2004 to 2011 and for the Philippines in 2004. The rescaled indicator is greater than 1 since the value in these years is greater than the maximum of the benchmark economies in any year. We constrain the value to be 1 in these cases.
} 


\section{Figure 1: Bank-Based versus Market-Based Financial Structure}
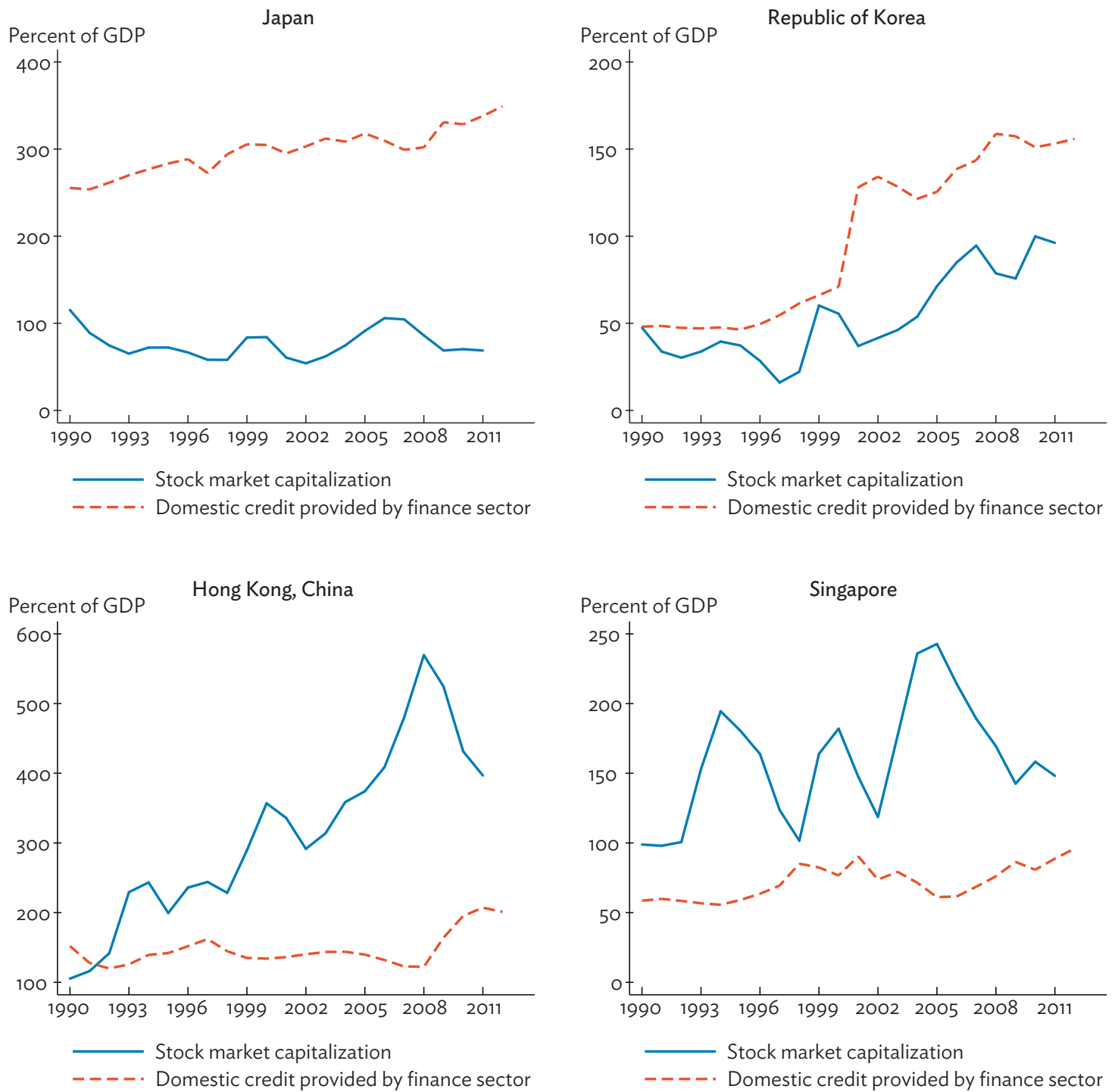

GDP = gross domestic product.

Source: World Bank, World Development Indicators. http://data.worldbank.org/data-catalog/world-development-indicators (accessed July through October 2014).

We faced the problem of missing data in our sample. While these variables were chosen keeping in mind that data are available for most economies, data for some indicators were missing for a few years, or a certain indicator may not have had any data for a particular economy. We therefore imputed data in these instances using simple rules that are available from the authors on request.

Using the normalized indicators we constructed a main index and three subindices:

(i) Index of financial development using all seven indicators;

(ii) Subindex for access using the number of commercial bank branches;

(iii) Subindex for efficiency using NIM and stock market turnover; 
(iv) Subindex for depth using domestic credit by the finance sector, stock market capitalization, M2/GDP, and value added of the finance sector.

While creating the indices, we needed to assign a weight to each indicator. Any method of aggregation requires making a judgment on the importance of a particular indicator in overall financial development. While there are a number of studies on the various aspects of financial development, the results do not give a conclusive sense that any one facet is more important than others. Hence we assumed that the indicators are equally important, and to keep the methodology simple and transparent, we assigned the same weights to each. This seems to be a preferred option in the construction of other similar indices such as the financial index for advanced countries in the International Monetary Fund (IMF) (2006) and the domestic financial development index for emerging economies in Dorrucci, Meyer-Cirkel, and Santabarbara (2009). While constructing the ease of doing business index, Djankov et al. (2005) showed that using other methods like principal components and unobserved components led to highly similar conclusions as the simple average method.

We constructed the index for each economy and each year. A higher value of the index indicates a higher level of financial development. Note that while aggregating, we included $(1-N I M)$ in the numerator since a lower value of NIM suggests higher efficiency.

\section{COMPARISON OF THE ASSOCIATION OF SOUTHEAST ASIAN NATIONS++ MEMBERS WITH THE BENCHMARK ECONOMIES}

In this section, we describe the indices for a subsample we call Association of Southeast Asian Nations (ASEAN)++. It includes six ASEAN members-Indonesia, Malaysia, the Philippines, Singapore, Thailand, and Viet Nam - and Australia; the PRC; Hong Kong, China; India; Japan; and the Republic of Korea.

\section{A. Where Are the ASEAN++ Economies in Relation to the Benchmark Group?}

In Figure 2, we plot the subindices of access, efficiency, and depth for each economy for the years 2004 and 2011. An average of the indices for the benchmark group is also plotted to view the distance of each from the benchmark. Across the time period considered, we see a movement of the index of each economy in relation to the benchmark group for that year.

Between 2004 and 2011, the benchmark index improved from 0.44 to 0.58 for efficiency, from 0.48 to 0.55 for depth, and fell slightly from 0.63 to 0.62 for access. Australia exceeded the benchmark in terms of access and was lower than the benchmark for depth in both years. While the efficiency subindex was above the benchmark in 2004, it fell below it in 2011.

In terms of movement, Malaysia moved significantly closer to the benchmark in terms of access from 2004 to 2011. It also improved in the efficiency corner, but its depth subindex lagged. Thailand again showed movement toward the benchmark in access, smaller movement in depth, and a move away from the benchmark in efficiency. India, Indonesia, and Viet Nam all showed declines in the efficiency subindex while the Philippines, on the other hand, had improved significantly by 2011 but was still some distance from the benchmark. In 2011, the PRC's efficiency subindex coincided with that of the benchmark group. 
Figure 2: Country Indices in Relation to the Benchmark Index
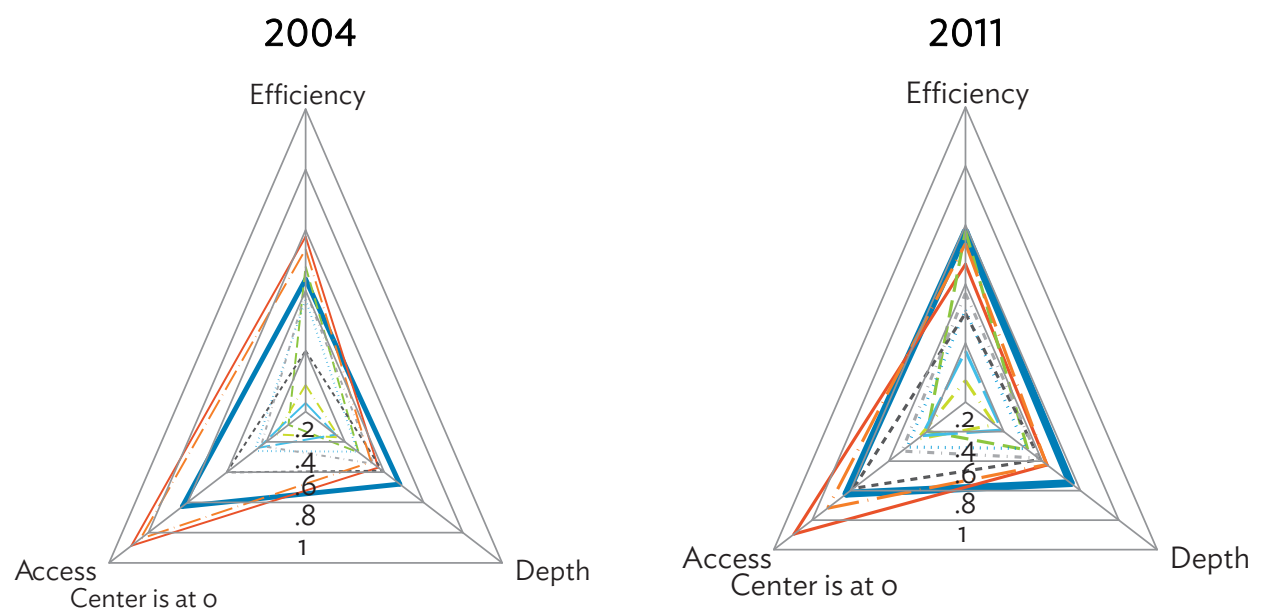

Center is at o

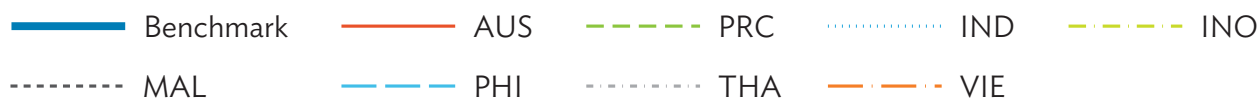

AUS = Australia, IND = India, INO = Indonesia, $M A L=$ Malaysia, $P H I=$ Philippines, $P R C=$ People's Republic of China, $T H A=T h a i l a n d$, VIE = Viet Nam.

Source: Authors' calculations.

Access improved in most economies in our sample except in Viet Nam where the subindex was also the lowest compared to the benchmark. After Malaysia and Thailand, the largest movement in the access subindex between 2004 and 2011 was in the PRC and Indonesia, though their levels were still low compared with the benchmark. Viet Nam showed the most improvement in terms of depth, while Indonesia showed a decline in this subindex between these years.

In terms of the overall index of financial development, the benchmark stood at 0.57 in 2011. Among the others, Malaysia, the PRC, and Thailand were high at $0.39,0.38$, and 0.37 respectively, while Indonesia, the Philippines, and Viet Nam were low at $0.14,0.19$, and 0.19 respectively. India's index in 2011 was in between at 0.31 .

Between the years 2004 and 2011, the financial development index improved in all the ASEAN++ group except in Indonesia where it remained the same, but the distance from the benchmark widened in all. After Australia, Malaysia was closest to the benchmark and Indonesia the furthest in 2011 compared with 2004 when the Philippines was the furthest from the benchmark index.

With regard to the four benchmark economies, by 2011 Hong Kong, China had the highest index of overall financial development followed by Japan and then the Republic of Korea. In 2004, Hong Kong, China and Japan had similar levels of financial development, but by 2011, the former surpassed Japan as the most financially developed economy in Asia. Although Singapore's level of financial development was the lowest among the four, the change in Singapore's financial development index was similar to that of Hong Kong, China. 
In sum, between 2004 and 2011, we found that outside of the benchmark group, improvement was greatest in financial access among the ASEAN++ group. Most economies showed slower improvement in financial market efficiency.

Finally, for a comparison with developed economies outside Asia, we constructed indices for the United States (US) and the United Kingdom (UK) 3 that are widely believed to have the most advanced financial systems in the world. According to our indices, however, their financial systems trail those of our Asian benchmark group. The overall index of financial development changed from 0.45 to 0.50 for the US and from 0.45 to 0.50 for the UK from 2004 to 2011. In both those years, their overall indices were lower than the index in the benchmark group mainly due to less depth. They outperformed the Asian benchmark in terms of access and underperformed (slightly) in terms of efficiency.

\section{B. What Factors Play a Role in Levels of and Changes in Financial Development?}

The literature discussed previously lists a number of factors that determine financial development such as GDP per capita, growth, openness, macroeconomic variables, technology, and institutional factors. We plotted the computed indices against some of these factors to analyze their role in levels of and changes in financial development. In all the following graphs, the economies are ranked by these factors based on data in 2010 (for example, GDP per capita in 2010), since the most complete data for these variables are available for this year.

Figure 3 shows the index of financial development in the years 2005 and 2011 for the ASEAN++ group. First we sorted the group by GDP per capita. As expected, richer economies in general had a higher level of financial development. Next we sorted them by inflation from low to high and saw that those with macroeconomic stability in terms of lower inflation tended to have greater financial development. These factors also matter particularly for the size of the financial system as depicted by the depth subindex.

The degree of financial openness also plays a role in determining the level of financial development. We ranked economies in order from highest to lowest based on the Chinn and Ito (2008) measure of openness. They were then divided into quartiles, and the average index of financial development was plotted from 2004 to 2011. As Figure 4 shows, economies in the uppermost quartile of financial openness also had the highest level of financial development. The same result was true in the depth subindex as well.

Another factor associated with both greater financial development and depth is the quality of institutions. We used the strength of legal rights index which varies from 0 to 10 to rank the sample. Since some economies had the same index, we obtained only three groups. A higher legal rights index is associated with higher levels of financial development as seen in the lower panel of Figure 4.

3 We used the series on financial intermediation, a category under value added by industries at current prices compiled from National Accounts. 
Figure 3: Factors Determining Financial Development, Ranked by Gross Domestic Product per Capita and Inflation

\section{Gross domestic product per capita}

Financial development index

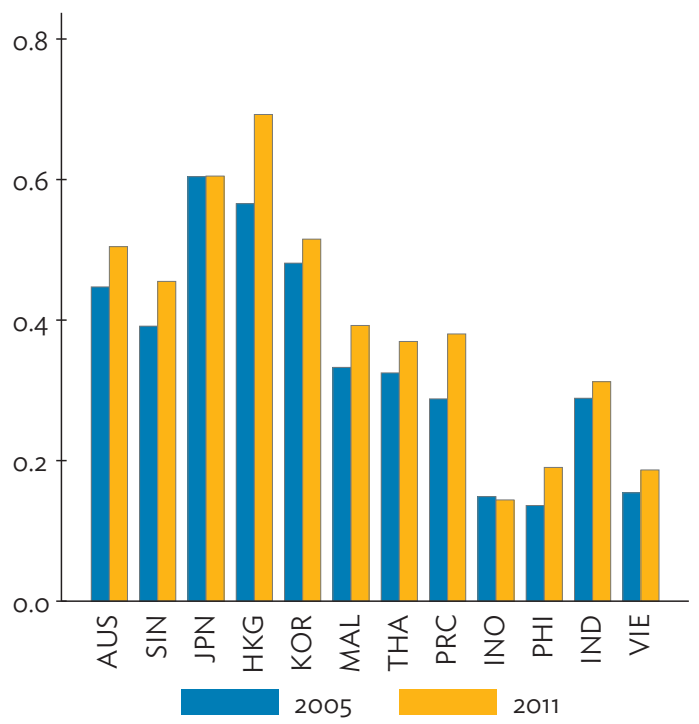

Depth subindex

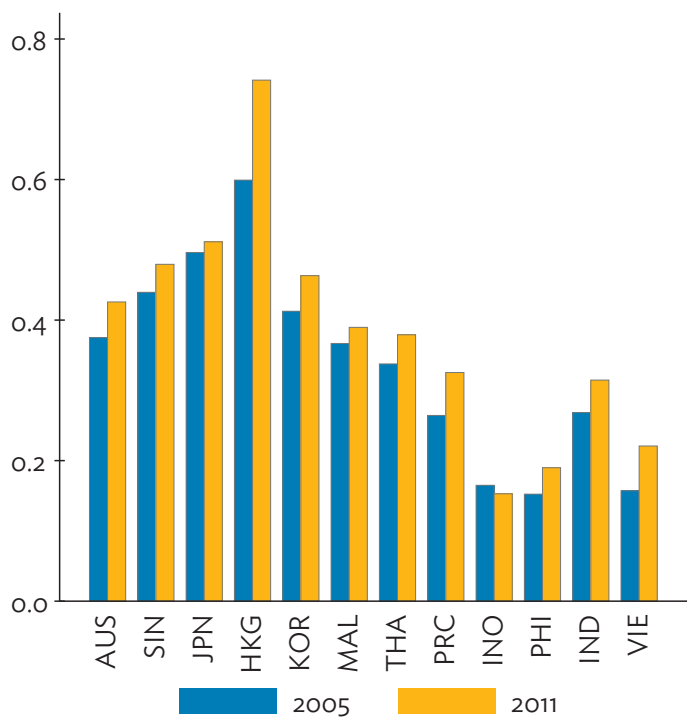

Inflation

Financial development index

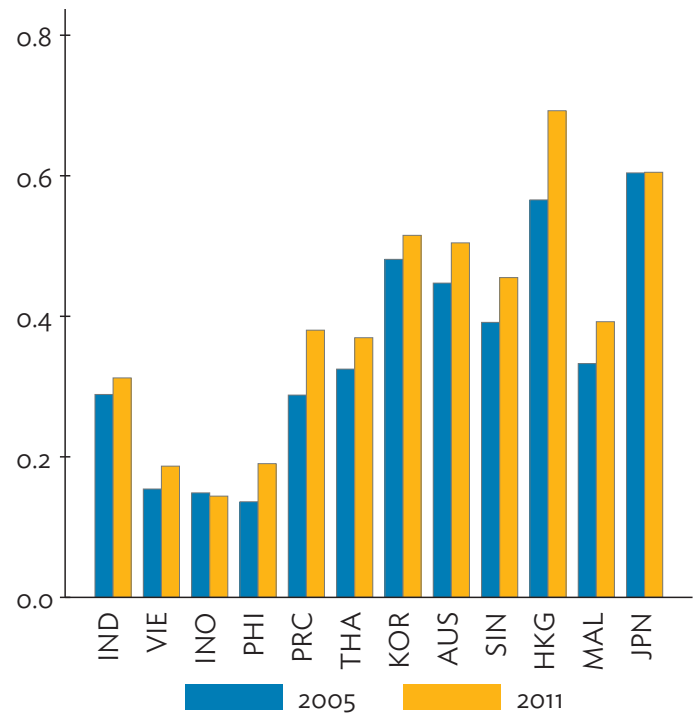

Depth subindex

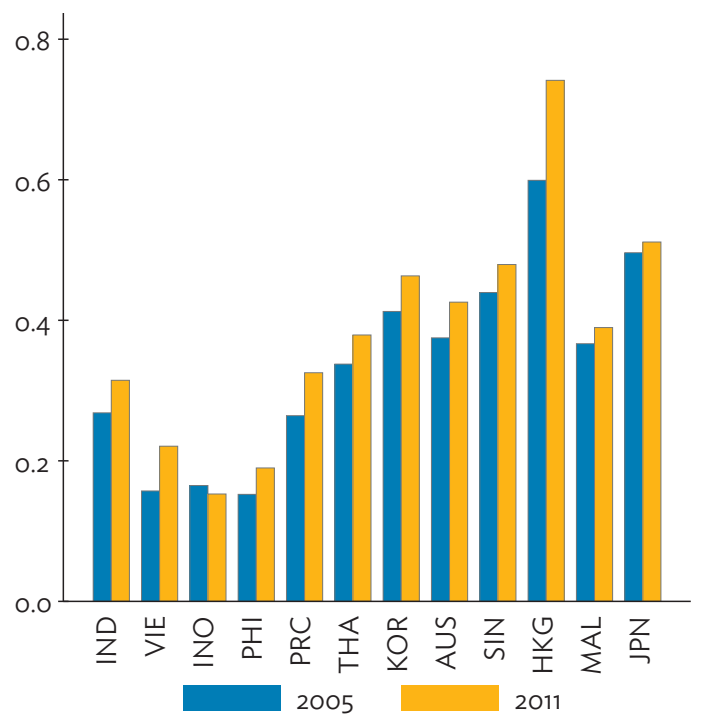

AUS = Australia; $\mathrm{HKG}=$ Hong Kong, China; IND = India; INO = Indonesia; JPN = Japan; $\mathrm{KOR}=$ Republic of Korea; $\mathrm{MAL}=\mathrm{Malaysia} ; \mathrm{PHI}=$ Philippines; PRC = People's Republic of China; SIN = Singapore; THA = Thailand; VIE = Viet Nam.

Sources: World Bank, World Development Indicators. http://data.worldbank.org/data-catalog/world-development-indicators (accessed July through October 2014); Authors' calculations. 


\section{Figure 4: Factors Determining Financial Development}

Financial openness

Financial development index

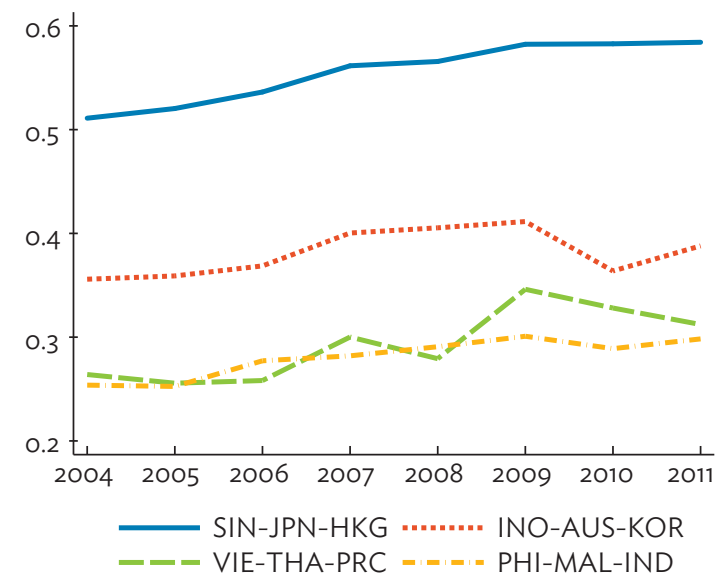

Depth subindex

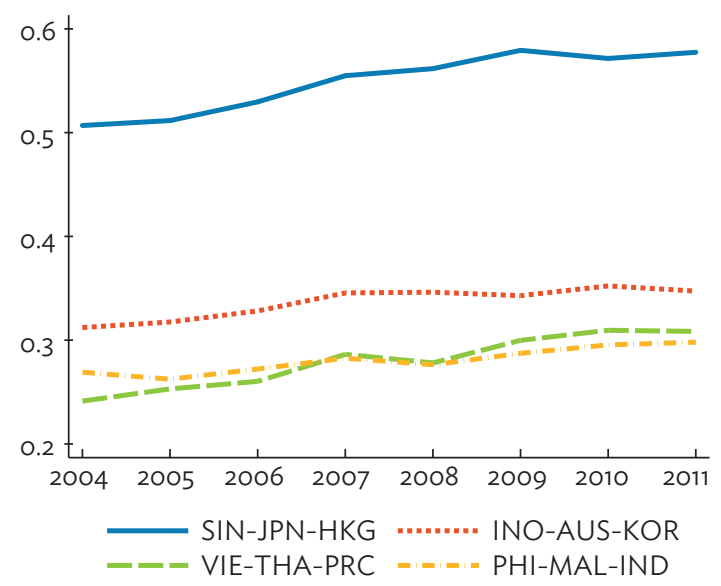

Legal rights

Financial development index

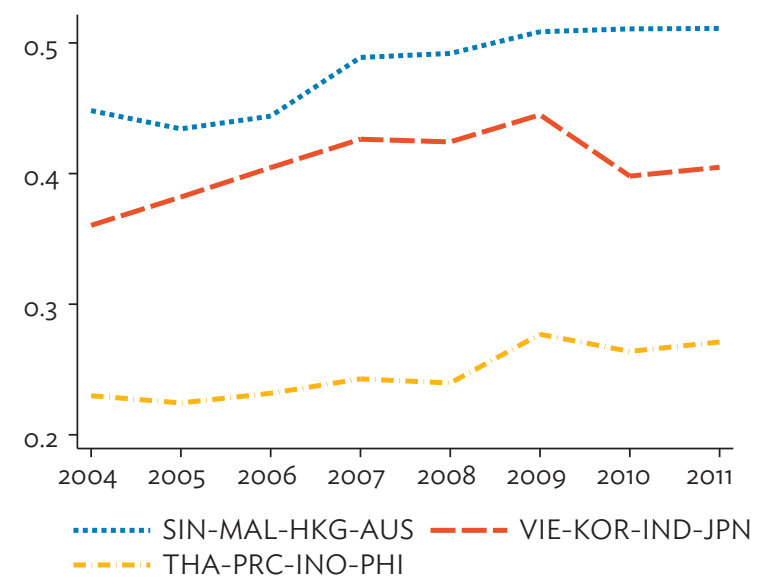

Depth subindex

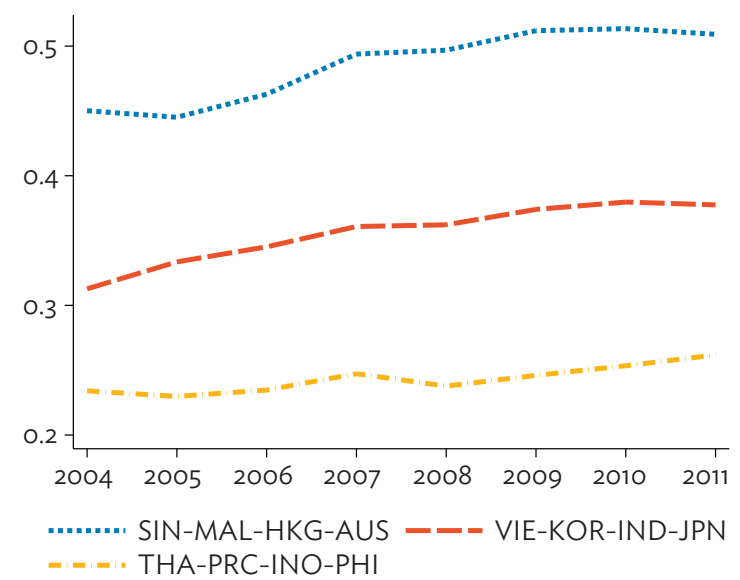

AUS = Australia; HKG = Hong Kong, China; IND = India; INO = Indonesia; JPN = Japan; $K O R=$ Republic of Korea; $M A L=M a l a y s i a ; P H I=$ Philippines; PRC = People's Republic of China; SIN = Singapore; THA = Thailand; VIE = Viet Nam.

Sources: Chinn and Ito 2008; World Bank, World Development Indicators. http://data.worldbank.org/data-catalog/world-developmentindicators (accessed July through October 2014); Authors' calculations.

We also examined the change in financial indices between the first and last years of available data to understand the role of certain factors in the process of financial development. In Figure 5, we ranked economies by a certain variable in 2010 , divided them into quartiles, and plotted the average change in their financial indices in each quartile. The left side of the graph shows that those with lower inflation had the largest increase in the financial index. Another factor is technology as those with the most mobile subscriptions had a greater change in the index as seen on the right side of the graph. 


\section{Figure 5: Factors Determining Change in Financial Development Index}

Inflation

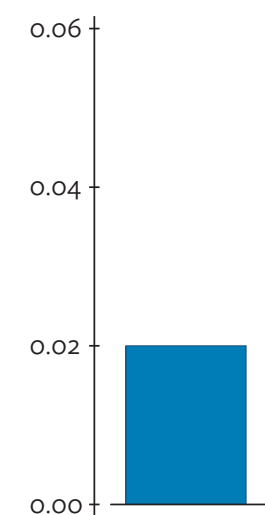

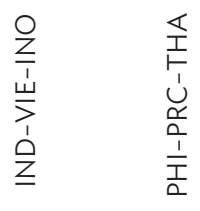

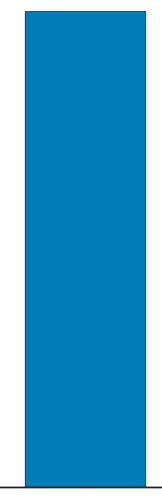

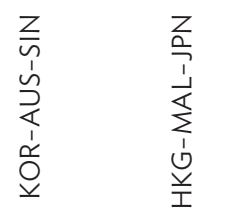

Mobile subscriptions

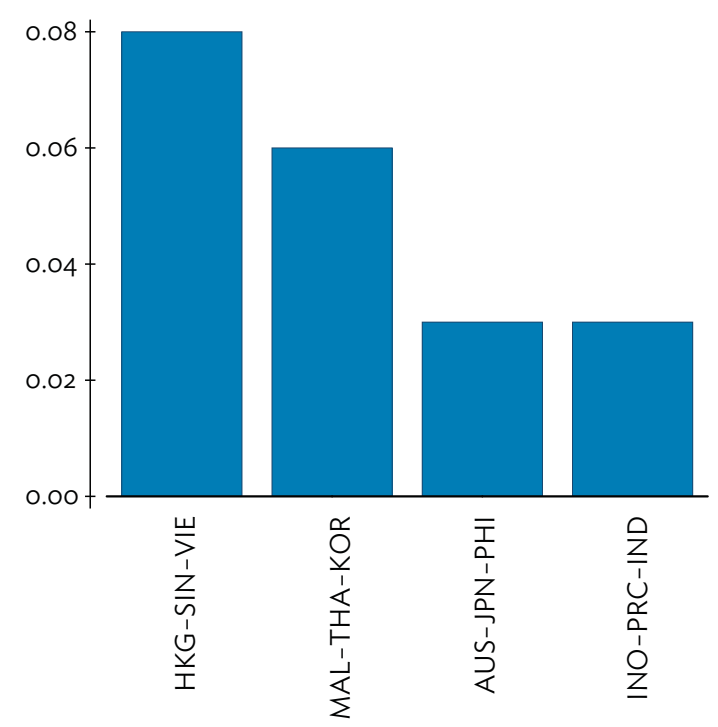

AUS = Australia; HKG = Hong Kong, China; IND = India; INO = Indonesia; JPN = Japan; KOR = Republic of Korea; MAL = Malaysia; PHI = Philippines; PRC = People's Republic of China; SIN = Singapore; THA = Thailand; VIE = Viet Nam.

Sources: Chinn and Ito 2008; World Bank, World Development Indicators. http://data.worldbank.org/data-catalog/world-developmentindicators (accessed July through October 2014); Authors' calculations.

\section{AN ECONOMETRIC ANALYSIS OF THE DETERMINANTS OF FINANCIAL DEVELOPMENT GROWTH}

We have shown graphically that financial development in many Asian economies appears to be converging to the levels of the benchmark group. The graphs also show that economic variables such as GDP per capita affect the speed of convergence. We then used panel data random effects estimates to more formally test whether there has been convergence in the development of financial systems in the region by examining a broader sample of 23 Asian economies excluding only those without a formal stock market without which it would be impossible to calculate our measures of financial development.

The results from our panel data econometric estimates are as follows. First, we found that there is indeed strong convergence in the financial systems in Asia. From 2004 to 2011, economies with weaker financial systems were catching up on average to those with stronger financial systems.

Second, we found that holding the level of financial development constant, richer economies (in terms of GDP per capita) had faster rates of financial development than poorer ones. This is not surprising in that in richer economies there is simply more demand for sophisticated financial instruments. Third, economic scale or the size of aggregate real GDP increases growth in financial development (in some specifications). Since the financial industry depends on economies of scale, the 
larger the economy, the larger the finance sector and the more efficient the finance industry. This finding may justify the "bulk up" policies of Singapore as they add more people through immigration. The increase in the population can raise the scale and efficiency of the economy, especially that of the finance sector. Fourth, mobile phone subscriptions strongly promote financial development. Our results are robust when we drop the per capita GDP variable and when we use instrumental variables. Fifth, while trade openness seems to promote financial development somewhat, capital market openness generally has no effect on it.

\section{A. The Data}

The construction of the financial development index follows the description in Section III.B. From the list of Asian Development Bank members, we dropped those without an organized stock market (especially Fiji and other Pacific island countries, among others). We next dropped those missing data on NIM. We were left with 23 members as our working sample (Table 1). Some of the key variables are depicted in Table 1. We can see that Singapore had the highest growth in its financial development from 2004 to 2011, followed by Hong Kong, China; the Republic of Korea; the PRC; and Mongolia. The countries with the lowest growth in financial development were Pakistan, the Kyrgyz Republic, Bangladesh, and Indonesia.

Table 1: Financial Development and Its Economic Determinants, 2004-2011

\begin{tabular}{|c|c|c|c|c|c|c|}
\hline Economy & $\begin{array}{c}\text { Change in } \\
\text { Financial } \\
\text { Development } \\
(2004-2011)\end{array}$ & $\begin{array}{c}\text { Level of } \\
\text { Financial } \\
\text { Development } \\
(2004)\end{array}$ & $\begin{array}{l}\text { Level of } \\
\text { Aggregate } \\
\text { GDP } \\
(2004)\end{array}$ & $\begin{array}{c}\text { Level of GDP } \\
\text { per Capita } \\
(2004)\end{array}$ & $\begin{array}{c}\text { GDP per } \\
\text { Capita } \\
\text { Growth } \\
(2004-2011)\end{array}$ & $\begin{array}{c}\text { Inflation } \\
\text { Rate } \\
(2004)\end{array}$ \\
\hline & & Index & \$ billion & \$ thousand & Percent & $\begin{array}{l}\text { Annual } \\
\text { percent }\end{array}$ \\
\hline Armenia & 0.047 & 0.08 & 3.58 & 1.18 & 189 & 6.96 \\
\hline Australia & 0.001 & 0.50 & 613.16 & 30.46 & 104 & 2.34 \\
\hline $\begin{array}{l}\text { Bangladesh } \\
\text { People's Republic }\end{array}$ & -0.010 & 0.20 & 56.56 & 0.40 & 83 & 7.59 \\
\hline of China & 0.077 & 0.30 & $1,931.64$ & 1.49 & 266 & 3.88 \\
\hline Georgia & 0.054 & 0.07 & 5.13 & 1.19 & 171 & 5.66 \\
\hline Hong Kong, China & 0.097 & 0.60 & 169.10 & 24.93 & 41 & -0.45 \\
\hline India & 0.018 & 0.29 & 721.59 & 0.65 & 137 & 3.77 \\
\hline Indonesia & 0.000 & 0.14 & 256.84 & 1.16 & 199 & 6.24 \\
\hline Japan & 0.023 & 0.58 & $4,655.80$ & 36.44 & 27 & -0.01 \\
\hline Kazakhstan & 0.052 & 0.07 & 43.15 & 2.87 & 295 & 6.88 \\
\hline Republic of Korea & 0.095 & 0.42 & 721.98 & 15.03 & 49 & 3.59 \\
\hline Kyrgyz Republic & -0.112 & 0.19 & 2.21 & 0.43 & 159 & 4.11 \\
\hline Malaysia & 0.054 & 0.34 & 124.75 & 4.92 & 105 & 1.52 \\
\hline Mongolia & 0.069 & 0.20 & 1.99 & 0.80 & 299 & 8.24 \\
\hline Nepal & 0.041 & 0.15 & 7.27 & 0.29 & 141 & 2.84 \\
\hline New Zealand & 0.008 & 0.50 & 102.98 & 25.19 & 47 & 2.29 \\
\hline Pakistan & -0.163 & 0.30 & 97.98 & 0.63 & 92 & 7.44 \\
\hline Papua New Guinea & 0.023 & 0.07 & 3.93 & 0.66 & 168 & 2.10 \\
\hline Philippines & 0.061 & 0.13 & 91.37 & 1.08 & 117 & 4.83 \\
\hline Singapore & 0.099 & 0.36 & 112.70 & 27.05 & 89 & 1.66 \\
\hline
\end{tabular}


Table 1 continued

\begin{tabular}{|c|c|c|c|c|c|c|}
\hline Economy & $\begin{array}{c}\text { Change in } \\
\text { Financial } \\
\text { Development } \\
(2004-2011)\end{array}$ & $\begin{array}{c}\text { Level of } \\
\text { Financial } \\
\text { Development } \\
(2004)\end{array}$ & $\begin{array}{c}\text { Level of } \\
\text { Aggregate } \\
\text { GDP } \\
(2004)\end{array}$ & $\begin{array}{c}\text { Level of GDP } \\
\text { per Capita } \\
(2004)\end{array}$ & $\begin{array}{c}\text { GDP per } \\
\text { Capita } \\
\text { Growth } \\
(2004-2011)\end{array}$ & $\begin{array}{c}\text { Inflation } \\
\text { Rate } \\
(2004)\end{array}$ \\
\hline Sri Lanka & 0.044 & 0.15 & 20.66 & 1.06 & 167 & 7.58 \\
\hline Thailand & 0.026 & 0.34 & 161.34 & 2.48 & 109 & 2.76 \\
\hline Viet Nam & 0.042 & 0.15 & 49.42 & 0.61 & 154 & 7.76 \\
\hline
\end{tabular}

$\mathrm{GDP}=$ gross domestic product.

Source: World Bank, World Development Indicators. http://data.worldbank.org/data-catalog/world-development-indicators (accessed July through October 2014); Authors' calculations.

\section{B. Panel Data Econometrics}

In our panel specifications, we regressed the first-difference, (the change) in financial development on the level of financial development in the previous year. The coefficient on the level of the financial development variable measures the direction of convergence. If the coefficient is negative and statistically significant, then the lower the level of financial development, the higher its subsequent growth. That is, on average, economies in Asia are catching up in financial development to our advanced Asian benchmark group. ${ }^{4}$

In Table 2, in addition to the level of financial development in the previous period we included GDP per capita, the level of inflation, the level of aggregate GDP, a measure of trade openness, a measure of mobile phone subscriptions, and a measure of capital market openness. The level of GDP per capita in the previous period captures how the general level of economic development affects a change in financial development. We would expect that holding the level of financial development constant, a higher level of GDP per capita would increase both the demand for financial services and the speed of financial development. The level of inflation in the previous period captures how inflation affects growth in financial development.

We expected that trade openness - the sum of exports plus imports divided by nominal GDP-would be positively correlated with growth in financial development. We further expected that the level of mobile subscriptions would increase the speed of financial development. Finally, we also expected the degree of capital market openness would stimulate the speed of domestic financial market development as foreigners and foreign market competition press the domestic financial system to liberalize and accelerate the adoption of best practices.

The random effects estimator that we adopted makes it difficult to determine whether time invariant characteristics such as legal rights or the prevalence of government banks can by themselves have an impact on the growth rate of financial development; however, we can still estimate the impact of time invariant institutions on finance sector convergence by interacting our institutional variables with the variable measuring the level of financial development. The coefficient on these interacted variables will then measure whether the institution in question will raise or lower the rate of finance sector convergence (Table 3).

4 Earlier, we tried a cross-section specification using only 2 years of data: 2004 and 2011. We regressed the change in financial development between 2004 and 2011 on the level of financial development in 2004. Because of the small number of observations of fewer than 20 economies, we could not obtain a statistically significant coefficient on the level of financial development in 2004. 


\section{Results}

Table 2 depicts our main estimates. ${ }^{5}$ For all of our specifications, we found that there is convergence in financial development. The coefficient of the variable FinDev(t-1), or the level of financial development in the previous period is always negative implying that on average between 2005 and 2011, if an economy has a lower level of financial development, financial development will be higher in the next period.

Table 2: Panel Data Random Effects Estimates (Dependent Variable: Change in Financial Development from Previous Year)

\begin{tabular}{|c|c|c|c|c|c|c|}
\hline & (1) & (2) & (3) & (4) & (4) & (5) \\
\hline \multicolumn{7}{|c|}{$\operatorname{Fin} \operatorname{Dev}(t-1)$} \\
\hline Coeff & -0.047 & -0.045 & -0.051 & -0.066 & -0.075 & -0.059 \\
\hline t-stat & $(-1.88)$ & $(-1.74)$ & $(-1.81)$ & $(-2.23)$ & $(-2.51)$ & $(-1.91)$ \\
\hline \multicolumn{7}{|c|}{$\operatorname{GDPCap}(t-1)$} \\
\hline Coeff ${ }^{1 /}$ & 0.62 & 0.64 & 0.69 & 0.59 & 0.49 & 0.76 \\
\hline t-stat & $(2.05)$ & (2.07) & $(2.25)$ & $(1.87)$ & (1.51) & $(2.06)$ \\
\hline \multicolumn{7}{|c|}{ Inflation(t-1) } \\
\hline Coeff & & 0.0002 & 0.0055 & 0.0005 & 0.00053 & 0.00047 \\
\hline t-stat & & $(0.35)$ & $(0.80)$ & $(0.87)$ & (0.91) & $(0.79)$ \\
\hline \multicolumn{7}{|c|}{$\operatorname{AggGDP}(t-1)$} \\
\hline Coeff $^{2 /}$ & & & 0.24 & 0.49 & 0.45 & 0.23 \\
\hline t-stat & & & $(1.07)$ & $(1.89)$ & $(1.80)$ & $(1.03)$ \\
\hline \multicolumn{7}{|c|}{ TradeOpen(t-1) } \\
\hline Coeff & & & & 0.0002 & & \\
\hline t-stat & & & & (2.19) & & \\
\hline \multicolumn{7}{|l|}{ Mobile(t-1) } \\
\hline Coeff & & & & & 0.00021 & \\
\hline t-stat & & & & & $(1.85)$ & \\
\hline \multicolumn{7}{|c|}{ Chinnopen $(t-1)^{3 /}$} \\
\hline Coeff & & & & & & -0.008 \\
\hline t-stat & & & & & & $(-0.36)$ \\
\hline R-squared & 0.24 & 0.22 & 0.14 & 0.18 & 0.13 & 0.15 \\
\hline \multicolumn{7}{|c|}{ Observations: 168} \\
\hline \multicolumn{7}{|c|}{23 Economies } \\
\hline \multicolumn{7}{|c|}{ Years: 2004-2011 } \\
\hline \begin{tabular}{ll} 
Notes: \\
No & Coefficie \\
2/ & Coeffici \\
3/ & Chinn-It \\
\multicolumn{2}{c}{ Source: Auth }
\end{tabular} & $\begin{array}{l}\text { ied by } 10{ }^{6} \\
\text { ied by } 10 .{ }^{6} \\
\text { si Measure }\end{array}$ & & & & & \\
\hline
\end{tabular}

5 Because we use lag-one variables, we had to drop 2004 from our panel regressions. 
The coefficient on the level of per capita output in the previous period was mostly positive. That is, holding constant the level of financial development, an economy with a higher per capita output level will have faster growth in financial development. The inflation rate variable was always insignificant implying that higher inflation neither hinders nor helps the speed of financial development. Economic scale or aggregate GDP was positive and marginally significant. Trade openness was also positive and marginally significant. An economy with a more open trade regime would have faster growth in financial development.

Table 3: Panel Data Random Effects Estimates: Interactive Effects with Institutional Variables (Dependent Variable: Change in Financial Development from Previous Year)

\begin{tabular}{|c|c|c|c|c|}
\hline & (1) & (2) & (3) & (4) \\
\hline \multicolumn{5}{|l|}{$\operatorname{FinDev}(\mathrm{t}-1)$} \\
\hline Coeff & -0.06 & -0.058 & -0.071 & -0.054 \\
\hline t-stat & $(-1.83)$ & $(-1.83)$ & $(-1.44)$ & $(-1.74)$ \\
\hline \multicolumn{5}{|l|}{ GDPCap (t-1) } \\
\hline Coeff $^{1 /}$ & 0.91 & 0.91 & 0.59 & 0.87 \\
\hline t-stat & $(2.25)$ & $(2.25)$ & $(1.82)$ & (2.33) \\
\hline \multicolumn{5}{|l|}{ GovBank*FinDev(t-1) } \\
\hline Coeff & & 0.0006 & & \\
\hline t-stat & & $(1.26)$ & & \\
\hline \multicolumn{5}{|l|}{ Legal*FinDev(t-1) } \\
\hline Coeff & & & 0.002 & \\
\hline t-stat & & & $(0.53)$ & \\
\hline Prompt*FinDev(t-1) ${ }^{2 /}$ & & & & -0.002 \\
\hline Coeff & & & & $(-0.73)$ \\
\hline \multicolumn{5}{|l|}{ t-stat } \\
\hline R-squared & 0.1 & 0.12 & 0.16 & 0.14 \\
\hline
\end{tabular}

Mobile subscriptions strongly affected the growth of the finance sector. This result should be viewed with some caution, however, since when mobile subscriptions are included in the regression, the level of per capita GDP becomes insignificant suggesting that mobile subscriptions and per capita income are highly correlated. With mobile subscriptions, we may simply be capturing the impact of higher per capita income. To investigate this further, we estimated the same equation but dropped the per capita GDP variable. The coefficient on the mobile subscription variable remained positive and significant implying that the possible correlation between mobile subscriptions and per capita GDP did 
not bias the coefficient on mobile subscriptions upwards. Thus our results suggest that technological sophistication and finance sector development go hand in hand.

Capital market openness as measured by the Chinn-Ito index was statistically insignificant. To control for various biases, we measured capital market openness with various instruments, but it remained insignificant.

Table 3 depicts the results when lagged financial development is interacted with some of the institutional variables. If the coefficient on the interacted variable is positive, it means that as the institutional variable in question increases, the speed at which financial convergence occurs increases. That is, financial convergence accelerates. We found, however, that all of the institutional variables that we tested were statistically insignificant.

Deakin, Demetriades, and James (2010) and others have pointed out that the dominance of government-owned banks typically hinders the development of the financial system as government banks may block the entry of more entrepreneurial private firms. We, however, found no evidence that increasing the dominance of government-owned banks would hinder the speed of development of the finance sector (Table 3, Column 2). ${ }^{6}$

In the third column of Table 3, we interacted the legal rights index with lagged financial development. The coefficient on this variable was insignificant suggesting that legal rights have no impact on the acceleration of financial development, at least among the Asian economies in our sample.

Finally, we examined if banking regulatory strength could hasten growth in financial development. We used an indicator of prompt and corrective action to proxy the strength of banking regulation. Prompt and corrective action refers to banking regulations that force the regulatory authorities to take action to improve the performance of banks if banking performance benchmarks fall below a certain level. We found that this indicator was insignificant (Column 4).

\section{WHICH ECONOMIES HAVE FINANCIAL SYSTEMS THAT PROMOTE POSITIVE ECONOMIC OUTCOMES?}

Armed with our indices and subindices of financial development by economy, we can ask the above question. Here we chose three overall economic goals: GDP growth, GDP variability, and financial access. GDP growth was measured as the average growth rate of an economy between 2005 and 2011. GDP variability was measured as the average of the absolute values of the deviation of annual GDPs from its average growth rate. An economy with smaller deviations of annual GDPs on average will have smaller GDP variability. To see how our financial indices relate to a separate independent measure of financial access, we took the number of bank accounts owned by individuals (as opposed to businesses) per capita. This measure was taken from a survey conducted in 2011 by Demirgüç-Kunt and Klapper (2013).

We proceeded in two steps. First, we calculated how important the subindices (financial efficiency, depth, and access) were in achieving the goals of high GDP growth, low GDP variability, and

6 The size of the government banking sector for an economy is measured as the percentage of banking system assets that are $50 \%$ or more government owned. 
a high number of bank accounts. We ran panel regressions from 2005 to 2011 of GDP growth and the inverse of GDP variability on our sample of 23 economies using the three subindices of efficiency, depth, and access for each one. We imposed the constraint that the coefficient of the three subindices must add to one. For our dependent variable of the number of accounts, since we had data for only 2011 we simply ran a cross-section regression using 2011 data on the three subindices for the sample.

The results are summarized in Table 4. For achieving high GDP growth, we found that depth in financial markets is most important, access is next, and efficiency is last. In lowering GDP variability, we found again that financial depth is most important by a wide margin and that efficiency is not important at all. For increasing the number of individual bank accounts per capita, not surprisingly access is most important followed by depth and finally efficiency.

In the second step, we took each economy's subindices for financial market depth, efficiency, and access to predict GDP growth, GDP variability, and financial market access. We used the estimated weights in Table 4 to make these predictions. We then used these predictions to rank financial systems according to their effectiveness in delivering each of the three economic outcomes.

For delivering high average GDP growth between 2005 and 2011, we found that the financial systems of Japan; the Republic of Korea; Hong Kong, China; Australia; and Singapore ranked the highest. The worst financial systems for delivering growth were Georgia, Armenia, Papua New Guinea, and Indonesia.

For delivering the lowest variability in GDP, we found that the financial systems of Hong Kong, China; Japan; Australia; New Zealand; Malaysia; and the Republic of Korea ranked the highest. The worst financial systems for delivering low GDP variability were the Kyrgyz Republic, Kazakhstan, Papua New Guinea, Armenia, and Indonesia.

For delivering financial access, i.e. the highest number of individual bank accounts per capita, Japan; the Republic of Korea; Hong Kong, China; Australia; Singapore; and New Zealand ranked the highest. Georgia, Armenia, Papua New Guinea, the Kyrgyz Republic, and Indonesia ranked the lowest.

Table 4: Accounting for Economic Outcomes: Financial Development Indices ${ }^{1 /}$

\begin{tabular}{|c|c|c|c|}
\hline Economic Outcomes & Efficiency & Depth & Access \\
\hline GDP growth & 0.09 & 0.59 & 0.31 \\
\hline Low GDP volatility & 0.00 & 0.86 & 0.14 \\
\hline $\begin{array}{l}\text { Number of individual } \\
\text { bank accounts }{ }^{2 /}\end{array}$ & 0.13 & 0.36 & 0.52 \\
\hline \multicolumn{4}{|c|}{$\begin{array}{l}\text { GDP = gross domestic product. } \\
\text { Notes: } \\
\text { 1/ Subindices weights add up to unity for each outcome. } \\
\text { 2/ } 2011 \text { from the World Bank, Global Financial Inclusion Database. } \\
\text { Source: Authors' calculations described in Section VI. }\end{array}$} \\
\hline
\end{tabular}




\section{CONCLUSIONS}

In this paper we have focused on the following question: Have the rest of the Asian economies been catching up with or converging on the financial systems of the Asian economies with advanced financial systems? Our empirical results show that the answer is an unequivocal yes. Our findings are the following.

First, between 2004 and 2011, the financial systems in weaker economies were catching up with or converging on the benchmark economies (Hong Kong, China; Japan; the Republic of Korea; and Singapore). Second, GDP per capita, aggregate GDP, and mobile subscriptions all increased the growth rate of financial development. Third, within Asia, institutional variables such as legal rights and the dominance of government banks had insignificant or ambiguous effects on changing the growth rate of financial development. Fourth, while Southeast Asian economies were catching up with the benchmark economies in overall financial development and in the subindex of financial access, convergence was slower in the subindex of financial efficiency. In particular, given the importance of mobile subscriptions in increasing the pace of financial development, our results suggest that Asian policy makers should further promote the use of mobile technologies in the finance sector. 


\section{REFERENCES}

Ang, J. B. and W. J. McKibbin. 2007. Financial Liberalization, Financial Sector Development and Growth: Evidence from Malaysia. Journal of Development Economics. 84 (1). pp. 215-233.

Billmeier, A. and I. Massa. 2007. What Drives Stock Market Development in the Middle East and Central Asia-Institutions, Remittances, or Natural Resources? International Monetary Fund Working Paper Series. No. 157. Washington, DC: International Monetary Fund.

Chinn, M. D. and H. Ito. 2008. A New Measure of Financial Openness. Journal of Comparative Policy Analysis. 10 (3). pp. 309-322.

Deakin, S., P. Demetriades, and G. A. James. 2010. Creditor Protection and Banking System Development in India. Economics Letters. 108 (1). pp. 19-21.

Demetriades, P. O. and K. A. Hussein. 1996. Does Financial Development Cause Economic Growth? Time-Series Evidence from 16 countries. Journal of Development Economics. 51 (2). pp. 387-411.

Demirgüç-Kunt, A. and L. Klapper. 2013. Measuring Financial Inclusion: Explaining Variation in Use of Financial Services Across and Within Countries. Brookings Papers on Economic Activity. Washington, DC: Brookings Institution.

Detriagiache, E., P. Gupta, and T. Tressel. 2005. Finance in Lower Income Countries: An Empirical Exploration. International Monetary Fund Working Paper Series. No. 05/167. Washington, DC: IMF.

Djankov, S., D. Manraj, C. McLiesh, and R. Ramalho. 2005. Doing Business Indicators: Why Aggregate, and How to Do It. Doing Business Team Report. Washington, DC: World Bank.

Djankov, S., C. McLiesh, and A. Shleifer. 2007. Private Credit in 129 Countries. Journal of Financial Economics. 84 (2). pp. 299-329.

Dorrucci, E., A. Meyer-Cirkel, and D. Santabarbara. 2009. Domestic Financial Development in Emerging Economies: Evidence and Implications. European Central Bank Occasional Paper Series. No. 102. Frankfurt: European Central Bank.

Gani, A. and C. Ngassam. 2008. Effect of Institutional Factors on Stock Market Development in Asia. American Journal of Finance and Accounting. 1(2). pp. 103-120.

International Monetary Fund (IMF). 2006. World Economic Outlook, Chapter 4. Washington, DC: International Monetary Fund.

La Porta, R., F. Lopez-De-Silanes, A. Shleifer, and R. W. Vishny. 1997. Legal Determinants of External Finance. The Journal of Finance. 52 (3). pp. 1131-1150.

Law, S. H. and P. Demetriades. 2004. Capital Inflows, Trade Openness and Financial Development in Developing Countries. Paper prepared for the Money Macro and Finance Research Group Conference. London. 6-8 September. 
Lyman, T. R., M. Pickens, and D. Porteous. 2008. Regulating Transformational Branch-Less Banking: Mobile Phones and Other Technology to Increase Access to Finance. Consultative Group to Assist the Poor Focus Note. Washington, DC: World Bank.

Rajan, R. G. and L. Zingales. 2003. The Great Reversals: The Politics of Financial Development in the Twentieth Century. Journal of Financial Economics. 69 (1). pp. 5-50.

World Bank. Global Findex Database. http://www.worldbank.org/en/programs/globalfindex

—_. World Development Indicators (WDI). http://data.worldbank.org/data-catalog/worlddevelopment-indicators

World Economic Forum (WEF). 2011. The Mobile Financial Services Development Report. Geneva. 


\section{The Recent Convergence of Financial Development in Asia}

We construct an index of financial development for 23 Asian economies based on subindices of access, depth, and efficiency of financial institutions and markets, and find evidence that economies with weaker financial systems are catching up to the Asian benchmark economies. Gross domestic product (GDP) per capita, aggregate GDP, and mobile subscriptions all increase the growth rate of financial development in Asian economies, while institutional factors have insignificant or ambiguous effects.

\section{About the Asian Development Bank}

ADB's vision is an Asia and Pacific region free of poverty. Its mission is to help its developing member countries reduce poverty and improve the quality of life of their people. Despite the region's many successes, it remains home to the majority of the world's poor. ADB is committed to reducing poverty through inclusive economic growth, environmentally sustainable growth, and regional integration.

Based in Manila, ADB is owned by 67 members, including 48 from the region. Its main instruments for helping its developing member countries are policy dialogue, loans, equity investments, guarantees, grants, and technical assistance. 